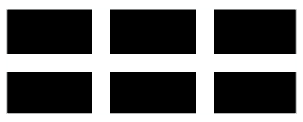

THE WILLIAM DAVIDSON INSTITUTE AT THE UNIVERSITY OF MICHIGAN BUSINESS SCHOOL

\title{
Mass Privatisation, Corporate Governance and Endogenous Ownership Structure
}

\author{
By: Irena Grosfeld and Iraj Hashi
}

William Davidson Institute Working Paper Number 596

July 2003 


\title{
Mass Privatisation, Corporate Governance and Endogenous Ownership Structure
}

\author{
Irena Grosfeld \\ Delta- Fédération Jourdan, CNRS, \\ 48, Boulevard Jourdan \\ 75014 Paris, France \\ e-mail : grosfeld@delta.ens.fr \\ and \\ Iraj Hashi \\ Staffordshire University Business School, Stoke on Trent, UK, \\ e-mail:..Hashi@staffs.ac.uk
}

This version:

July 2003

Keywords: Corporate governance, privatization, transition, ownership structure.

JEL codes: G3, L2, P3, P5 


\section{Abstract}

We compare the change in ownership concentration in firms privatized through two different programs of mass privatization: the Czech voucher scheme and the Polish program of National Investment Funds. Despite important differences in ownership structure at the start of the process and in the quality of legal and regulatory environments, the emerging ownership patterns are remarkably similar: in the two groups of firms we observe high concentration and the emergence of industrial corporations and individuals as important dominant shareholders.

Given the important evolution of ownership, we take ownership structure as endogenous and look at its determinants. We find in particular that ownership concentration depends on the degree of uncertainty in the firm's environment. In a more risky environment firms tend to have more dispersed ownership. We interpret this result in the light of the recent theories of the firm stressing the trade-off between managerial initiative and shareholder control. 


\section{Introduction ${ }^{1}$}

In several countries of Central and Eastern Europe special privatisation strategies have been used in order to transfer assets from the state to the private sector. These strategies, often qualified as 'mass privatization', strongly relied on a free transfer of equity of a large number of firms to large segments of the population. Since the beginning, mass privatization was strongly criticised as being 'artificial' and unable to provide firms with 'real owners' or to bring about improvement in their performance. One of the main criticisms concerned the dispersed ownership structure that mass privatisation was expected to generate. The implicit argument was that diffused ownership structure is inefficient because it is unable to guarantee good corporate governance and deep enterprise restructuring.

Concentrated ownership has benefits which have been analysed by a large body of the literature initiated by Berle and Means (1932). Indeed it is often considered as the main corporate governance mechanism which, through improved monitoring, can alleviate the conflict of interest between self-interested managers and value maximising owners. However, another body of the literature developed more recently, stresses the cost of concentrated ownership. Large block ownership leads to, for instance, 'private benefits of control' that allow majority shareholders to expropriate the minority. Moreover, in various circumstances the control imposed by strong owners on managers may be too severe, restraining their initiative and incentives. High ownership concentration may also increase the risk of the owner in control. Finally, there is a trade-off between ownership concentration and liquidity which may affect the informational role of the stock market.

Given these various trade-offs, it becomes difficult to define a priori the characteristics of a 'good' ownership structure. Therefore in this paper, which tries to evaluate the effectiveness of mass privatization, we do not intend to compare the emerging ownership structure to a benchmark. We rather look at the extent of the evolution of the ownership structure in mass privatised firms since the initial allocation of property rights. We focus on firms privatised according to two quite different schemes: the voucher scheme in the Czech Republic and the National Investment Funds (NIF) programme in Poland.

We start with a short review of the literature devoted to the relationship between ownership concentration and firm performance. We stress the ambiguity of the predictions generated by this literature. Next, we briefly characterise the mass privatisation strategies in Poland and the Czech Republic and assess the extent of the reallocation of property rights after the initial privatisation push. We provide statistical evidence on the actual evolution of firms' ownership. It turns out that the ownership structure has rapidly evolved: it has become highly concentrated and the identity of the largest shareholders has quickly changed. So, contrary to the concern of the critics of mass privatisation programmes, the inertia of the initial ownership structure was quite limited. Finally, in the last part of the paper, we take ownership structure as endogenous and try to identify its determinants. We consider indeed that in firms privatised through mass privatization schemes the endogeneity of ownership may be a particularly important problem. Therefore, instead of treating ownership as exogenous, and trying to capture its impact on firm performance, we try to determine how it adjusts to various firm specific characteristics as well as to factors characterising the firm's environment. We are particularly interested in testing the relationship between firm specific uncertainty and

\footnotetext{
${ }^{1}$ We are grateful to Dr. Erjon Luci and Bartlomiej Paczoski for valuable research assistance.
} 
William Davidson Institute Working Paper 596

ownership concentration. We find that, contrary to the traditional agency cost view of the firm, and in line with the theories stressing the cost of excessive control of managers, the higher the riskiness of the firm, measured by the share of intangibles in firm's assets, the lower the ownership concentration.

\section{Ownership structure and firm performance: Ambiguous relationship}

\subsection{Theory}

There is a large and rapidly growing body of the literature studying the impact of ownership structure on firm performance. Most of the literature considers that corporate ownership structure has a significant effect on corporate governance and performance. Following the early work by Berle and Means (1932) and until the eighties, this literature has focused on the advantages of ownership concentration. The main concern was the cost of the separation of ownership and control, or the agency costs (Jensen and Meckling, 1976; Fama and Jensen, 1983; etc.). The idea is that dispersed ownership in large firms increases the principal-agent problem due to asymmetric information and uncertainty. Because the contracts between managers and shareholders are unavoidably incomplete (future contingencies are hard to describe), shareholders must monitor managers. There is a widespread consensus that a higher degree of control by an external shareholder enhances productivity performance: more monitoring presumably increases productivity (Shleifer and Vishny, 1986). When the equity is widely dispersed, shareholders do not have appropriate incentives to monitor managers who, in turn, can expropriate investors and maximise their own utility instead of maximising shareholder value. Concentrated ownership in the hands of outsiders is also often advocated on the ground that it facilitates the provision of capital. ${ }^{2}$

More recently, the focus of the literature has shifted and several theories have been proposed to show the ambiguity of the effect of ownership concentration. La Porta et al. (1998b) show that, in the majority of countries, large corporations have large shareholders who are active in corporate governance. Consequently, they argue, monitoring managers is not the main problem of corporate governance and the real concern is the risk of the expropriation of minority shareholders. A similar view has been expressed by the Becht and Roell (1999) in their review of corporate governance in continental European countries. In most of the countries studied, companies have large shareholders and the main conflict of interest lies between them and minority shareholders. On the other hand, dispersed ownership may have a beneficial impact on firm performance. If concentrated ownership provides incentives to control the management, it may also reduce the manager's initiative or incentives to acquire information (this is our interpretation of Aghion and Tirole, 1997). In this perspective, Burkart et al. (1997) view dispersed ownership as a commitment device ensuring that shareholders will not exercise excessive control. If the principal is concerned with providing the manager with the guarantee of non-intervention, he may choose to commit not to verify

\footnotetext{
2 Another way of alleviating the agency cost is managerial ownership. This is supposed to align managerial interests and shareholder's interests (Jensen and Meckling, 1976). A number of studies have found a non-linear relationship between managerial shareholdings and firm value: low levels of managerial ownership increase firm value but at higher levels of managerial ownership firm value decreases. The latter result was interpreted as managerial entrenchment (cf. for instance Morck et al., 1988; McConnell and Servaes, 1990; Holderness et al., 1999).
} 
the action of management. Such inefficient monitoring technology may stimulate managerial activism (Cremer, 1995), creating, ex-ante, powerful incentives for the management.

Moreover, dispersed ownership implies higher level of stock liquidity which, in turn, improves the informational role of the stock market (Holmström and Tirole, 1993). Using the stock exchange as the source of information is particularly important, again, in the situation of high uncertainty (Allen, 1993), or when it is essential to ensure that the management of underperforming firms changes hands. Finally, concentrated ownership is costly for large shareholders because it limits diversification and reduces the owners' tolerance towards risk (Demsetz and Lehn, 1985, Heinrich, 2000). Ownership dispersion allowing greater risk diversification may positively affect investment decisions. Allen and Gale (2000) conclude that in the second best world of incomplete contracts and asymmetric information, separation of ownership and control may be optimal for shareholders. Overall, however, the existing economic theory does not offer a clear prediction of the concentration-performance relationship. Bolton and von Thadden (1998) claim that "the issue is not whether ownership concentration per se is desirable or not. The issue rather is how often and at what points in firm's life ownership should be concentrated".

\subsection{Empirical Evidence}

The ambiguity of theoretical predictions concerning the impact of ownership structure on firm performance is confirmed by the existing empirical evidence. Short (1994) reviewing the literature points out that no conclusions can be drawn about the real effect. ${ }^{3}$ It is often considered (see for instance De Miquel et al., 2001 and Himmelberg et al., 1999) that the ambiguity of the results may be due to two main problems that plague the empirical analysis: unobservable heterogeneity and potential endogeneity of ownership. Unobservable heterogeneity means that there are firm specific characteristics that are difficult to measure or difficult to obtain and which do not enter the model. If individual characteristics (e.g. of the firm environment) are not taken into account, the results may be biased. We can control for heterogeneity by including individual effects. Endogeneity of ownership means that unobservable characteristics may also influence firm performance. In such case ownership is an endogenous variable in firm value models. If we ignore this potential effect we may get a spurious correlation between ownership structure and firm value.

The transition economics literature is particularly rich in attempts to identify the impact of ownership and privatisation on firm performance (for surveys see Carlin et al., 1995; Carlin, 1999; Djankov and Murrell, 2000). This literature usually compares the performance of privatised with state-owned enterprises; it also tries to capture the effect of ownership by

\footnotetext{
${ }^{3}$ Some authors find a relationship between ownership and firm value or firm performance, others find no significant relationship. Mc Connel and Servaes (1990), considering both insider ownership and blockholder ownership, find positive but insignificant relation. The results of Nickell et al. (1997) are inconclusive and point out the importance of the type of owner: control by a financial company improves performance whereas control by a non-financial company tends to be negatively correlated with productivity growth. Leech and Leahy (1991) do not get clear-cut results either: they show that the correlation between performance and concentration depends on the concentration variable chosen. Finally, Bianco and Casavola (1999) find a negative correlation between ownership concentration and profitability on a panel of Italian firm. They interpret this result stressing the importance of selection of controlling individuals. The concentration of ownership may have made control insufficiently contestable. Zingales (1994) find a positive relation between ownership and performance.
} 
different dominant groups. However, these studies are hardly comparable: they use different methodological approaches, employ different performance measures, different time periods, etc. The studies that take into account the problem of the selection bias find that privatisation brings about significant and positive change in firms' behaviour particularly in Central and Eastern Europe (see, for instance, Frydman et al., 1999; Grosfeld and Nivet, 1999).

If the impact of privatisation and ownership structure on firm performance is difficult to identify, it is not only because of the problem of firm heterogeneity. Another problem is the issue of complementarity. There is an increasingly wide consensus that in order to be effective privatisation requires appropriate institutional reform. The experience of transition shows indeed that the effect of privatisation depends on a number of factors characterising firm environment. It appears that strong complementarities exist between privatisation and the quality of business environment, determined by such factors as institutional infrastructure (including law enforcement); development of financial markets; degree of product market competition; macroeconomic stability, etc. For instance, in countries with weak institutional environment, privatisation may not bring about expected effects. The fact that in CIS countries it is more difficult than in CEE countries to identify the effect of private property on firm performance (e.g. Djankov and Murrell, 2000) may precisely be attributed to the lack of some of these necessary complementary factors which make privatisation work.

A recent study of firm performance in transition (Grosfeld and Tressel, 2002) provides an evidence of complementarity between product market competition and ownership concentration. The impact of product market competition depends on the ownership structure of the firm. Competition has no significant impact on productivity growth in firms with 'poor' governance ${ }^{4}$; it has a significant and positive effect in the case of firms with 'good' corporate governance. So, competitive pressure, at least in the case of the Polish listed firms, did not compensate for the weakness of corporate governance mechanisms. Therefore, competition and corporate governance appears as complements rather than substitutes. This result can be considered as evidence that competition policies and ownership changes should be promoted simultaneously. Transformation strategy focusing solely on competition may not be successful if it is not accompanied by efficient ownership changes.

Most of the empirical work on the relationship between ownership and firm performance supposes that there is a link between ownership and firm performance. So it considers ownership as an exogenous factor and analyses the differences in performance of firms with different ownership concentration and with different types of owners. There is however another strand of empirical literature, triggered by Demsetz (1983) and Demsetz and Lehn $(1985)^{5}$ which has questioned this hypothesis. In these works ownership structure, instead of being considered as exogenous, is rather viewed as endogenously determined. Firms have different characteristics, they are subject to different constraints, and operate in different environments with different types of competitive pressures. Consequently, the optimal ownership structure varies across firms and may be considered as an equilibrium solution responding to all these factors and constraints. Such perspective could be traced back to Coase. According to Coase, the distribution of property rights has no effect on economic efficiency, provided they are clearly defined and there are no transaction costs.

\footnotetext{
${ }^{4}$ Given that the authors find a U-shaped effect of ownership concentration on firm performance, poor corporate governance is identified with the intermediate level of ownership concentration which has a negative impact on firm productivity growth.

${ }^{5}$ Demsetz and Villalonga (2001); Himmelberg et al. (1999).
} 
Demsetz and Lehn (1985) and Demsetz and Villalonga (2001) explicitly take ownership structure as endogenous and view its evolution as consistent with value maximisation. ${ }^{6}$ They show, in a cross-section sample, that ownership concentration is related to various characteristics of firms, in particular their size, the degree of the regulation of the given industry and the benefits that owners can gain by increasing their monitoring effort. The authors maintain that if the firm operates in an uncertain environment (proxied by the volatility of the stock prices) there is scope for the owners to gain some of the potential profits through better monitoring.

Himmelberg et al. (1999) followed Demsetz and Lehn (1985) but focused on the determinants of managerial ownership stakes and used more sophisticated econometric techniques, allowing unobservable heterogeneity to be taken into account. They used panel data to investigate the impact of observable and unobservable firm characteristics on the ownership stakes of managers. They find that managerial ownership and firm performance are determined by common characteristics, i.e., managerial ownership should be treated as endogenous.

\section{Mass Privatisation and after: reallocation of equity stakes in the Czech Republic and Poland.}

In the Czech Republic and Poland rapid privatization was recognised as a fundamental element of transformation. Despite broad similarity of their reform programme, the two countries embarked on two different variants of mass privatisation (briefly described in Appendix 1). Various political and social considerations played a role. Most importantly, the choice was determined by the policy makers' understanding of the role of privatisation in market processes. In Poland privatisation was seen as a means of improving firm incentives and its real objective was firm restructuring. More orthodox methods of privatisation (IPOs, negotiated sales, auctions, etc.) were seen as more efficient from that point of view, but it soon became clear that relying exclusively on such methods would be too slow. Therefore, the NIF programme was initiated. The design of this programme was dominated by the concern about corporate governance arrangements favouring enterprise restructuring. In particular, a concentrated ownership structure was imposed on the firms and the funds were to be managed by highly experienced western specialists.

In the Czech Republic (and before that in Czechoslovakia) privatisation was understood as the precondition for the emergence of a market environment. It was viewed as the key element of the process of radical institutional change and was supposed to generate important spill over effects. Consequently, the main concern was the speed of the process and less attention was paid to the emergence of a specific ownership structure.

The comparison of the regulations of the securities markets in Poland and in the Czech Republic reveals two different philosophies underlying the two mass privatisation programmes. Poland is usually given as an example of a good regulatory strategy for other countries in transition (see Glaeser et al., 2001) while the Czech Republic is blamed for the

\footnotetext{
${ }^{6}$ In the transition context ownership is considered as endogenous in Jones and Mygind (1999).
} 
William Davidson Institute Working Paper 596

weakness of its regulatory framework. Indeed, the Polish authorities were concerned with the proper development of financial markets in general, and the stock exchange in particular and focused on the creation of a well established legal system and enforceable laws. Concerning the NIF programme, the remuneration scheme for NIF's managers, and the stock exchange listing requirements were carefully designed to ensure that this process is carried out openly and that the minority investors were not expropriated. The main concern was to avoid excessive dispersion of ownership and to provide companies with 'effective owners', somebody capable and willing to enforce control over management. The authors of the programme were apparently influenced by the economic theory stressing the importance of concentrated ownership structure for effective corporate governance. They were, however, also concerned with the potential danger of private benefits of control and imposed the limit of 33 per cent on the lead fund's holdings in each company.

These guarantees were deemed unnecessary in the Czech Republic: there was a fear that state intervention will create impediments to a rapid development of market institutions. The Company law and the laws governing the operation of securities markets were very lax and the supervision of securities trading and the associated agents were initially left to a department in the Ministry of Finance. Privatised companies were listed on the stock exchange without having to publish a prospectus and to obtain the approval of the securities regulator.

Despite differences in the motivations of mass privatisation, both countries believed that the initial ownership structure was temporary and that, under competitive pressure, it would gradually evolve towards a more effective structure. However, given the weakness of the regulatory framework in the Czech Republic and better protection of shareholders in Poland, it could be expected, relying on the 'law matters' argument of La Porta et al. (1998a), that we would observe lower ownership concentration in Poland than in the Czech Republic. Let us look, therefore, at the statistical evidence on the ownership changes following the initial allocation of ownership stakes in the two mass privatisation schemes. Without trying to evaluate whether the changes in ownership concentration converge to some 'optimal' model, we simply want to establish how flexible the ownership structures are.

\subsection{The Data}

The data on Czech companies comes from a Czech commercial company (Aspekt) who relied on official company accounts filed by joint stock companies and on Prague Securities Centre (for the identity of owners). Employment and other information were collected from company reports. The financial data is annual and covers the period of 1993-99. The data-set was purchased in early 2000 and consequently the information for 1999 is not complete for all

companies. The ownership data includes the identity and the equity holdings of up to seven largest shareholders of each company since 1996. The owners are categorised into six types: industrial companies, investment funds, portfolio companies (companies engaged primarily in buying and selling of shares without any intention of interfering in management decisions), banks, individuals, and the state. Given that banks only have shareholding in a small number of firms, we have combined the holdings of 'portfolio companies' and 'banks' under 'other financial institutions'. 
William Davidson Institute Working Paper 596

The data set covers the large majority of mass privatised companies. There is, however, no information on the ownership structure of companies that have left the stock exchange (because of de-listing, change in their legal status, mergers and takeovers, or bankruptcy and liquidation). Also for some of the sample companies where ownership stakes are smaller than $10 \%$, the information on ownership is unavailable. Altogether, of the approximately 1700 mass privatised companies, we have financial information for 1326 and ownership information for 1246 firms respectively for the 1996-98 period ( 3 years), and for 626 and 652 firms, respectively, for the 1996-99 period (4 years). However, the number of firms with both financial and ownership data is smaller, 1077 (for 1996-98) and 276 (for 1996-99). Both samples are well distributed across the 20 sectors of economic activity (based on Prague Stock Exchange classification of sectoral activity which closely resembles NACE classification).

The Polish data were collected from several sources. The Ministry of State Treasury (Department of Privatisation) keeps some rudimentary data on the 512 companies in the National Investment Fund Programme, largely for the period before their privatisation. The Department keeps a record of major changes in the status of the companies. Additional information was collected from the annual reports of NIFs and their portfolio companies through the publication Monitor Polski, NIF's reports and the reports of the Association of National Investment Funds. For some of the companies that have been floated on the stock exchange, further information was obtained from the Warsaw Stock Exchange.

Unlike in the Czech Republic, the initial ownership structure of the companies in the mass privatisation scheme was uniform and fixed by the scheme (lead fund $33 \%$; other funds $27 \%$; employees $15 \%$ and the state $25 \%$ ). The information on ownership change in the following years, collected from the variety of sources described above, identifies the largest owners of those companies which have been divested by NIFs. The shareholders are classified into six categories: other companies (domestic), other companies (foreign), financial institutions, employees of the company, individuals and other NIFs.

\subsection{The evolution of ownership structure}

We focus on two dimensions of the evolution of ownership. First, we investigate whether ownership concentration has increased or decreased. Second, we describe the reallocation of block holdings between different groups: individual shareholders, investment funds, other financial institutions, industrial companies, and the state.

\section{Czech Republic}

The evidence from the Czech data points to an unambiguous increase in concentration of ownership. Table 1 highlights the broad picture of this evolution for a balanced sample from 1996 to 1999. 
Table 1.

The average share of the largest shareholder in the firms privatised through the voucher scheme

\begin{tabular}{lcccc}
\hline & 1996 & 1997 & 1998 & 1999 \\
\hline Mean & 38.8 & 42.8 & 48.6 & 51.9 \\
\hline Median & 36.3 & 42.0 & 47.5 & 49.7 \\
\hline Std. Dev. & 19.3 & 20.4 & 21.5 & 21.8 \\
\hline No. of firms & 652 & 652 & 652 & 652 \\
\hline
\end{tabular}

Source: Own calculation using Aspekt data-base

The average holding of the largest shareholder of companies in the sample increased rapidly from $38.8 \%$ in 1996 to $51.9 \%$ in 1999 . The $33 \%$ increase over a four-year period is an indication of a very dynamic evolution of ownership. The median figure indicates that by 1999 , half of the sample firms had one shareholder with almost $50 \%$ of the firm's equity - a dramatic increase in concentration if we remember that these firms, on the whole, had widely dispersed ownership after privatisation. If we take the share of the largest three or five shareholders, as alternative measures of ownership concentration, we get a very similar pattern. ${ }^{7}$

The evolution of ownership can also be measured by the extent of the reallocation of ownership rights between five different types of shareholders: industrial companies ${ }^{8}$; investment funds; other financial institutions, individuals and the state. By 'controlling owner' we refer to the largest shareholder owning more than $50 \%$ of a company's shares. ${ }^{9}$ The changes in the controlling shareholder of the sample firms over the fouryear period, between 1996 and 1999 are presented as a transformation matrix in Table $2 .^{10}$

Table 2 shows the number of companies that have moved from one type of controlling owner to another. For example, in 1996, 129 companies had 'an industrial company' as their controlling owner. By 1999, as a result of the transactions in the intervening period, the number of companies in this group had increased to 227 . The increase came from sale and purchase of shares resulting in the transfer of 'dominance' of 8 companies from 'investment funds', 13 from 'other financial institutions', 3 from the state, 4 from 'individuals' and 100 from the group with no dominant owner.

\footnotetext{
7 These results are available on request.

${ }^{8}$ This refers to another company engaged in some economic activity other than buying and selling of shares.

${ }^{9}$ Other authors (La Porta, et al., 1998b; Grosfeld and Tressel, 2002) use a 20\% shareholding as the control threshold. We use a higher threshold in order to highlight the extent of ownership changes experienced by Czech firms.

${ }^{10}$ A similar transformation matrix showing the change in firms' dominant ownership groups was also used in Estrin and Rosevear (1999) for Ukraine and in Jones and Mygind (1999) for Estonia.
} 
Table 2.

Ownership transformation matrix: number of firms having changed their controlling shareholder*, 1996-1999

\begin{tabular}{|c|c|c|c|c|c|c|c|}
\hline \multirow[b]{2}{*}{$\begin{array}{l}\text { Type of the controlling } \\
\text { owner* }\end{array}$} & \multirow[b]{2}{*}{$\begin{array}{l}\text { Number of } \\
\text { firms } \\
\text { according to } \\
\text { the type of } \\
\text { controlling } \\
\text { owner in } 1996\end{array}$} & \multicolumn{6}{|c|}{$\begin{array}{l}\text { Number of firms according to the } \\
\text { type of controlling owner in } 1999\end{array}$} \\
\hline & & 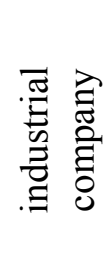 & 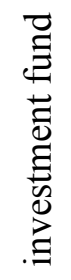 & 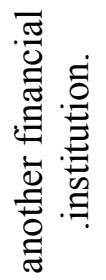 & 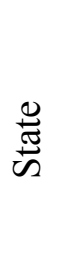 & 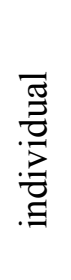 & 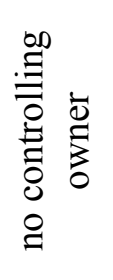 \\
\hline industrial company & 129 & 99 & 2 & 3 & 0 & 7 & 18 \\
\hline $\begin{array}{l}\text { investment Fund } \\
\text { another financial }\end{array}$ & 18 & 8 & 7 & 0 & 0 & 0 & 3 \\
\hline institution & 18 & 13 & 2 & 0 & 0 & 1 & 2 \\
\hline State & 12 & 3 & 0 & 0 & 4 & 1 & 4 \\
\hline individual & 22 & 4 & 3 & - & - & 9 & 6 \\
\hline no controlling owner & 476 & 100 & 23 & 10 & 2 & 18 & 323 \\
\hline Total & 675 & 227 & 37 & 13 & 6 & 36 & 356 \\
\hline
\end{tabular}

* Controlling shareholder refers to the largest shareholder of a company, provided he holds at least $50 \%$ of shares. Each row shows the number of companies in each dominant ownership group in 1996 (first column) and how they have moved to other ownership groups by the end of $1999\left(2^{\text {nd }}-7^{\text {th }}\right.$ columns $)$. Each column shows the total number of companies in each dominant group in 1999 (the last row) and their original dominant ownership group. The diagonal cells show the number of companies whose controlling shareholder type did not change between 1996 and 1999.

In the same period, the number of companies with an individual as the controlling owner increased from 22 to 36 and those with an investment fund as the controlling shareholder from 18 to 37 . On the other hand the number of companies with another financial institution or the state as the controlling shareholder decreased, from 18 to 13 (for the former) and from 12 to 6 (for the latter). ${ }^{11}$

Finally, we link the evolution of ownership concentration with the type of the largest owner. We consider three thresholds and four groups of ownership concentration (C1). Beyond $50 \%$ of equity shares the owner has absolute control over the company. With intermediate-high levels of ownership concentration (more than $33 \%$ and up to $50 \%$ ), the owner has substantial control. The intermediate-low concentration range (between 10\% and $33 \%$ shareholding) enables the owner to exercise some control over the firm's affairs. Finally, when the level of ownership concentration is low (less than 10\%) ownership is

\footnotetext{
${ }^{11}$ Given the important role of banks (which are included in the 'other financial institutions' group) in the Czech voucher scheme, it should be pointed out that they exercised both direct and indirect influence over privatised companies. Banks were the dominant shareholders of only 17 companies in 1996 and 7 in 1999. But their indirect influence was exercised through the bank-sponsored investment funds - and not through direct shareholding. Indeed, banks were shareholders of any significance in only 97 companies (in 1996) and this was reduced to 32 (in 1999).
} 
dispersed and the largest owner has little control over the firm's affairs. ${ }^{12}$ For each ownership concentration range we identify the largest shareholder and show in Table 3 how these have changed over the four years for a balanced panel of 652 companies.

Table 3.

Distribution of firms by ownership concentration and by the type of the largest shareholder*, 1996-1999

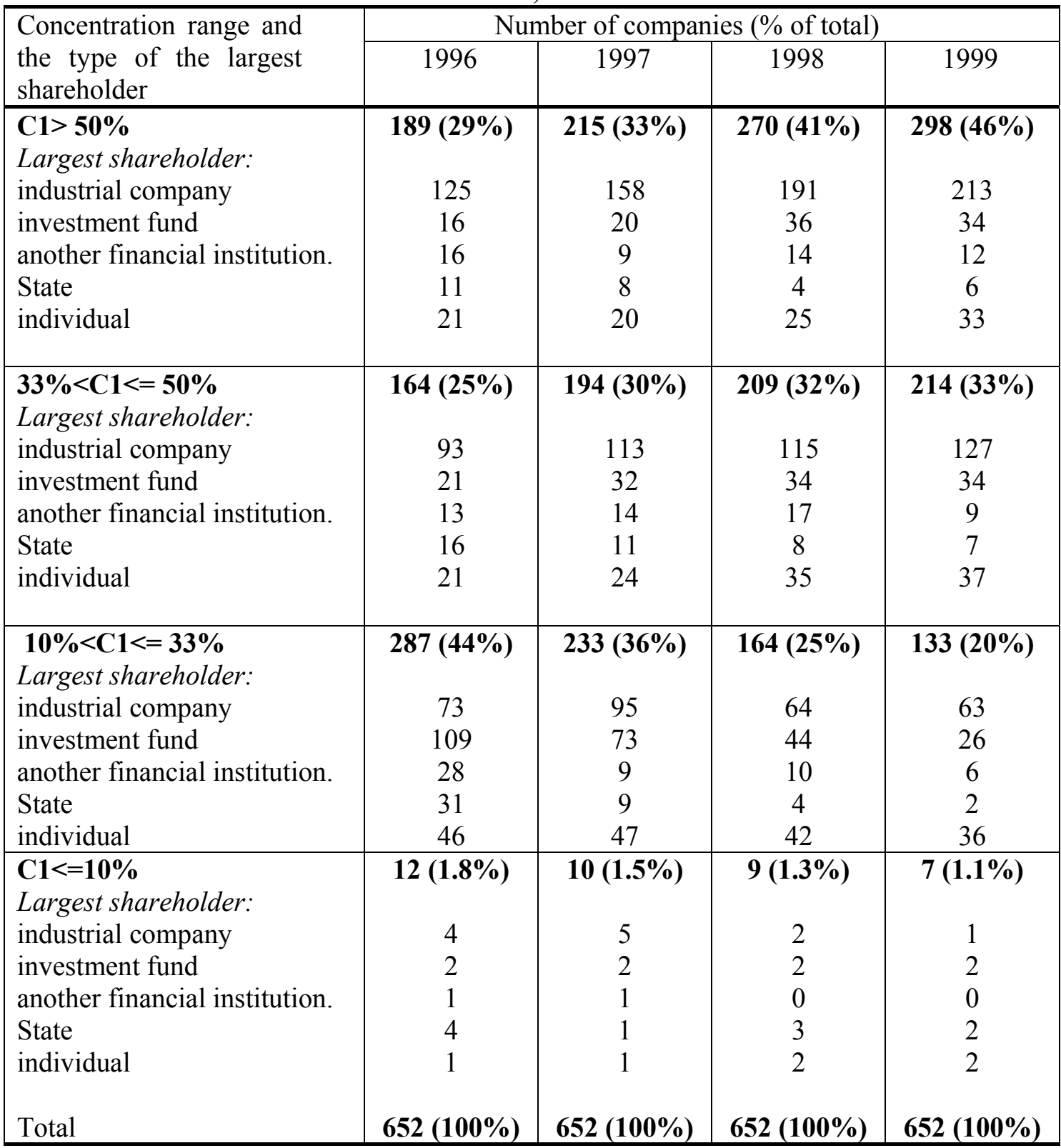

* Ownership concentration is measured by the share of the largest owner in the firm's equity, C1.

Source: Own calculations.

\footnotetext{
${ }^{12}$ These thresholds also have a legal dimension in the Czech Republic. Owners have to declare their identity once their ownership level reaches $10 \%$. They have to make an offer to buy out other shareholders once they reach the $33 \%$ threshold. The significant minority shareholders (33-50\%) enjoy certain legal privileges.
} 
Table 3 reveals several features of the evolution of ownership concentration. Firstly, we can see that the number of firms with absolute shareholder control (more than 50\%) has strongly increased from $29 \%$ in 1996 to $46 \%$ in 1999 and those with intermediate-to-high concentration has increased from $25 \%$ in 1996 to $33 \%$ in 1999 . The number of companies with intermediate-to-low ownership has fallen from $44 \%$ in 1996 to $20 \%$ in 1999. It must be stressed that in the immediate post-privatisation, the ownership of companies was widely dispersed. Only in $6 \%$ of firms there were owners holding more than $50 \%$ of shares (and most of these were cases where shares were allocated to NPF through the design of the privatisation project of the firm) (cf. Mejstrik, 1997, pp. 69-72).

Secondly, we look at the reallocation of shares between different types of dominant owners. Initially, only the state (through the National Property Fund) and investment funds held significant blocks of shares. Table 3, however, displays a significant reallocation of shares between 1996 and 1999. By 1999 two groups had emerged as significant new owners: other companies and individuals. Portfolio companies and banks (i.e., other financial institutions) play a role but hold very limited equity holdings in firms in their portfolio. The direct role of banks (which during this period were mostly stateowned) and the state itself had diminished significantly with only a few companies in which these two groups have remained as the largest shareholder.

Overall, we can see that three types of owners (industrial companies, individuals and investment funds) have increased the number of companies under their control, at the expense of other shareholders. The general picture is one of a dynamic market for sale and purchase of ownership claims, the dominant shareholder having changed in about $35 \%{ }^{13}$ of the companies in the four years under consideration. An important outcome of the process has been the emergence of individual entrepreneurs as the largest shareholders. In a country, in which there were initially no private (legal) entrepreneurs, this is a truly fundamental change.

\section{Poland}

The Polish scheme, due to its cautious design, had a degree of inertia built into it. Dominant owners, i.e., the 'lead funds' holding initially $33 \%$ of company shares, could not increase their share in portfolio companies until they were floated on the stock market or their capital was increased. At the same time, portfolio companies could not be floated on the stock market until they could meet (as any listed company) the stringent listing criteria set by the regulatory agency. These restrictions on trading of shares did not stop NIFs from reducing the number of firms in their portfolios. It seems that the combination of NIF's incentive system and the competitive pressure from the product and factor markets led to significant reallocation of property rights.

Table 4 shows that the mean share of the largest owner began to increase from 1996, initially by only a small fraction (as in the previous years it was 33\%), and then by larger amounts. By the year 2000, the largest shareholders were, on average, in near-absolute

\footnotetext{
13 The total number of firms whose dominant ownership has changed can be calculated by subtracting the sum of the diagonal figures in Table 2 from the total number of firms.
} 
control of their companies. The differences in the initial ownership structure notwithstanding, the process is very similar to that in the Czech Republic.

Table 4.

Average share of the largest shareholder in companies included in the National Investment Funds programme, 1966-2000

\begin{tabular}{|l|c|c|c|c|c|}
\hline & $\mathbf{1 9 9 6}$ & $\mathbf{1 9 9 7}$ & $\mathbf{1 9 9 8}$ & $\mathbf{1 9 9 9}$ & $\mathbf{2 0 0 0}$ \\
\hline Mean & 33.94 & 36.63 & 41.25 & 46.25 & 48.28 \\
\hline Std. Dev. & 5.29 & 10.03 & 15.67 & 20.38 & 22.76 \\
\hline Median & 33 & 33 & 33 & 33 & 33 \\
\hline No. of firms & 512 & 512 & 512 & 512 & 512 \\
\hline
\end{tabular}

Source: Own calculation

Table 5 shows the rapid evolution in the post-privatisation period of equity holdings of the state and of National Investment Funds in their portfolio companies.

Table 5.

Changes in the equity holdings of the State and of National Investment Funds in the firms included in the NIF programme in Poland

\begin{tabular}{|l|c|c|c|c|c|c|c|}
\hline & $\mathbf{1 9 9 4}$ & $\mathbf{1 9 9 5}$ & $\mathbf{1 9 9 6}$ & $\mathbf{1 9 9 7}$ & $\mathbf{1 9 9 8}$ & $\mathbf{1 9 9 9}$ & $\mathbf{2 0 0 0}$ \\
\hline $\begin{array}{l}\text { Mean state } \\
\text { shareholdings* }\end{array}$ & 100 & $\begin{array}{c}54.07 \\
(33.07)\end{array}$ & $\begin{array}{c}25.35 \\
(4.88)\end{array}$ & $\begin{array}{c}23.62 \\
(5.15)\end{array}$ & $\begin{array}{c}22.40 \\
(6.29)\end{array}$ & $\begin{array}{c}21.82 \\
(7.04)\end{array}$ & $\begin{array}{c}21.50 \\
(7.01)\end{array}$ \\
\hline $\begin{array}{l}\text { No of firms with } \\
\text { 0\% state equity }\end{array}$ & 0 & 0 & 0 & 0 & 4 & 60 & 99 \\
\hline $\begin{array}{l}\text { Mean } \\
\text { shareholding of } \\
\text { the lead NIF* }\end{array}$ & 33.00 & 33.00 & 32.94 & 33.89 & 34.93 & 35.50 & 35.78 \\
$(0.02)$ & $(0.02)$ & $(3.77)$ & $(5.88)$ & $(9.03)$ & $(10.43)$ & $(10.88)$ \\
\hline $\begin{array}{l}\text { No of firms with } \\
\text { 0\% NIF equity }\end{array}$ & 512 & 170 & 7 & 58 & 143 & 206 & 239 \\
\hline
\end{tabular}

* The mean value is calculated only for the companies, which still have the state or NIFs among their shareholders. Standard deviations are in parentheses.

The state has clearly withdrawn from active participation in the affairs of NIF companies. In 99 companies, it has reduced its holding to zero, while its average share in the remaining companies has fallen to about $20 \%$ level. As far as NIFs are concerned, they have completely withdrawn from 239 firms and have and left the companies to the new owners. Interestingly, the share of lead NIFs in their portfolio companies has slightly increased and stabilised at about $36 \%$.

At the beginning of the Polish mass privatization process, only NIFs and the state were the players involved. Other owners entered the process gradually. Table 6 shows the largest shareholders in 2000 and the extent of the reallocation of shares between the new and old owners. 
Table 6.

The largest shareholder in NIF companies, 2000.

\begin{tabular}{|l|c|c|}
\hline $\begin{array}{l}\text { Identity of the largest } \\
\text { shareholder } \\
\text { (at least } 15 \% \text { of equity) }\end{array}$ & $\begin{array}{c}\text { Number of } \\
\text { firms in } \\
2000\end{array}$ & $\begin{array}{c}\text { Equity holdings in } \\
\%, \text { mean, (Std. } \\
\text { Dev.) }\end{array}$ \\
\hline $\begin{array}{l}\text { Domestic investors } \\
\text { Of which: }\end{array} \quad 193$ & $58.61(21.11)$ \\
$\quad$ employees & 13 & $55.35(17.36)$ \\
$\quad$ individual & 48 & $55.04(22.70)$ \\
$\quad$ industrial firm & 116 & $60.59(20.28)$ \\
$\quad$ financial institution & 10 & $32.78(37.94)$ \\
another NIF & 6 & $35.42(29.35)$ \\
Foreign investor* & 52 & $73.72(25.21)$ \\
\hline
\end{tabular}

* For firms with a foreign investor we do not impose the $15 \%$ threshold of equity holdings.

In the five year period, $245 \mathrm{NIF}$ companies have been transferred to strategic investors, with $20 \%$ of them (52 companies) sold to foreign investors. Concerning the concentration of ownership stakes, it is striking that, on average, most strategic investors have gained absolute control (more than $50 \%$ ) of the firms' equity. Only financial institutions and other NIFs, on average, hold about $33-35 \%$ of shares. The employees, who were given special privileges in the Polish mass privatization, have acquired control of 13 companies. The highest ownership concentration can be observed in firms bought by foreign investors.

On the other hand we know that 80 companies (15\% of the companies in the scheme) went bankrupt or have entered the bankruptcy or liquidation processes. 36 companies (about $7 \%$ of the companies in the scheme, 25 of them with strategic investors) have satisfied the listing conditions set by the Warsaw Stock Exchange and are currently quoted on the WSE. These numbers go a long way to meeting the initial objectives of the programme and are in sharp contrast with the usually negative assessment of the scheme commonly found in the Polish and international economic press. To be sure, we do not try to compare the value of the firms before and after mass privatisation but simply try to assess how extensive the reallocation of property rights has been.

\section{Determinants of ownership: the expected relationship}

In the previous section we showed that the ownership of firms included in the mass privatisation programmes in the Czech Republic and Poland has undergone important changes. These changes were unusually rapid and the question of the determinants of these changes appears particularly legitimate. Beyond the fact that the trading of shares in firms included in the mass privatisation schemes reflected the desire to change the initially imposed (Poland) or inefficient (the Czech Republic) ownership structures, the changes in the latter certainly responded to a variety of firm specific characteristics or factors representing the environment in which it operates. In what follows we try to identify such determinants of 
William Davidson Institute Working Paper 596

ownership structure in our sample of Czech firm (the limitations of our NFI data make such exercise impossible for the Polish sample).

We focus on the following explanatory variables:

\section{Size}

It is usually expected that larger firms will be less likely to be highly concentrated. Purchasing large equity shares in a large company is more expensive than doing the same in a smaller company. Moreover, the concern of diversification also suggests that owners will be less likely to commit a larger fraction of their wealth to shares of one firm. In the previous studies (Demsetz and Lehn, 1985) firm size was inversely related to ownership concentration. Size may be proxied by several indicators such as assets, employment and sales. In this study, we use company sales (at constant 1995 prices) as a measure of size.

\section{Investment and leverage}

In order to control for various firm specific characteristics we include, beside the size, the rate of investment, firm leverage and whether or not the firm in question was privatised in the first wave of the voucher scheme. The level of investment undertaken by the firm influences its future prospects and may lead to the current and potential shareholders to increase their holdings. We use the rate of net investment (the ratio of net investment to fixed assets of the firm) to represent this variable. Leverage is measured as the ratio of total debt (short term and long term) of the firm to its total assets.

\section{Type of shareholders}

It is important to distinguish between different types of block holders because the emergence of a dominant owner and the scope of its control may strongly depend on who he is. For example, a corporate shareholder may have different motivation to acquire large stakes in another firm than a financial institution. We use dummy variables for each type of shareholders.

\section{Risk and uncertainty}

Following Demsetz and Lehn (1985) and Himmelberg et al. (1999) we expect that firm ownership structure may be affected by firm specific risk. Relying on the agency theory of the firm, Demsetz and Lehn (1985) and Himmelberg et al. (1999) have argued that if a firm operates in a fairly stable market, its managerial performance can be monitored quite easily and owners will not gain much by increasing their ownership stakes and monitoring. In such perspective, ownership concentration is viewed as the main corporate governance mechanism alleviating, through improved monitoring, the conflict between self-interested managers and value maximising owners. Indeed, Demsetz and Lehn believe that in a noisier environment, there is greater opportunity for managerial shirking and, at the same time, greater benefit in monitoring by owners. In such a situation risk is supposed to positively affect ownership concentration.

However, as we discussed in section 2.1, less concentrated ownership may stimulate managerial initiative. Such initiative may be expected to be particularly important if the firm environment is characterised by a high degree of uncertainty. In these cases, controlling and 
monitoring the managers may turn out to be less important than providing them with some latitude to make effort and engage in searching for new opportunities and innovations. Consequently, the prediction concerning the relationship between risk and ownership concentration would be opposite to the previous one: the greater the risk, the lower the ownership concentration. ${ }^{14}$

It is not easy to choose a good proxy for the degree of uncertainty in firm environment. Demsetz and Lehn (1985) and Himmelberg, et al. (1999) use standard deviation of monthly average share prices for this purpose but this indicator is not available for the large majority of firms in our sample which are not traded on the stock exchange. Instead, we propose to use intangible assets of a firm as an indicator of the uncertainty facing its shareholders. If intangible assets are low (low uncertainty) there is less need for the imaginative and innovative actions of managers, so more concentrated ownership may have lower cost in terms of suppressing manager's initiative. Given the nature of data collection in transition economies we believe that the information on tangible assets (as opposed to intangibles) is more clearly understood and more easily collected. We therefore use the ratio of tangible assets in total assets of a company as a measure of the lack of uncertainty in the firms' environment.

Another way of taking into account the nature of the uncertainty facing firms is to include industry specific dummies. Some industries are more likely to have dispersed ownership than other industries because of the nature of their activities requiring, for instance, different degrees of monitoring.

\section{Econometric specification}

We investigate two different dimensions of the process of evolution of ownership: the concentration of ownership, and the probability for a firm of having a large owner.

\subsection{Level of ownership concentration}

The dependent variable is the level of ownership concentration in a given firm in 1999, the last year for which we have data in our sample. Most of the independent variables (except dummies and ownership variables) are averages calculated over the previous periods. We use the following model to explain the level of ownership concentration:

$$
\begin{aligned}
& L C 1=\alpha+\beta_{1} \text { SIZE }+\beta_{2} \text { TANGIBLES }+\beta_{3} \text { INVESTMENT }+\beta_{4} \text { LEVERAGE }+ \\
& \beta_{5} \text { FIRSTWAVE }+\sum_{j=1}^{4} \not j O W N E R T Y P E+\sum_{k=2}^{20} \lambda_{k} I N D U S T R Y_{k}+\varepsilon
\end{aligned}
$$

\footnotetext{
${ }^{14}$ In the context of transition characterised by high degree of uncertainty about what should be produced and how, the competence of those who manage and control the firm, and their initiative, seems to be the most important factor of success. Recognising the trade off between monitoring and initiative suggests that leaving some degree of control in the hands of managers may be desirable. See Grosfeld (2002).
} 
LC1 is the logistic transformation of the share of the largest shareholder in company $\mathrm{i}$ in 1999 , $\left(\mathrm{LC} 1=\log (\mathrm{C} 1 / 100-\mathrm{C} 1){ }^{15} \mathrm{SIZE}\right.$ is measured by natural logarithm of sales (in constant 1995 prices), averaged between 1996 and 1998; TANGIBLES is the ratio of tangible assets to total assets of company, averaged between 1996 and 1998; INVESTMENT is the net investment ratio of firm $\mathrm{i}$ (net investment in year $\mathrm{t}$ divided by total assets in that year) averaged between 1996 and 1998; LEVERAGE is the ratio of total debt to total assets of firm averaged between 1996 and 1998. FIRSTWAVE is a dummy for firms privatised in the first wave of the voucher scheme; OWNERTYPE represents dummies for each of the five types of owners in 1999. INDUSTRY ${ }_{\mathrm{k}}$ is a set of 20 dummies indicating the sector to which the firm belongs. The full list of variables is presented in Appendix 2. The results are presented in Table 7.

Table 7.

\section{Determinants of ownership concentration}

\begin{tabular}{lc}
\hline & Coefficient \\
\hline SIZE & 0.293 \\
TANGIBLES & $(1.024)$ \\
& $0.534^{* *}$ \\
LEVERAGE & $(1.961)$ \\
& 0.639 \\
INVESTMENT & $(1.557)$ \\
& -0.03 \\
FIRST WAVE & $(-0.283)$ \\
& -0.151 \\
TYPE OF OWNER & $(-1.092)$ \\
& \\
industrial company & $0.922^{* * *}$ \\
investment fund & $(3.150)$ \\
& $0.507^{*}$ \\
another financial institution & $(1.634)$ \\
& $0.644 *$ \\
individual & 1.784 \\
Industry dummies & 0.487 \\
Constant & $(0.554)$ \\
No. of observations & \\
Adj R & Yes \\
& $-1.395^{* * *}$ \\
\hline
\end{tabular}

Notes: ${ }^{a}$ Dependent variable is the logistic transformation of the share of the largest shareholder. T-ratios in brackets; $*$ significant at $10 \%$; ** significant at $5 \%$; and $* * *$ significant at $1 \%$. See Appendix 1 for the definition of variables.

\footnotetext{
${ }^{15}$ The LC1 measure has also been used by Demsetz and Lehn (1985); Himmelberg et al. (1999) and others. It converts a bounded number (the simple percentage measure which varies from 0 to $100 \%$ ) to an unbounded figure.
} 
The most interesting result is the large, positive and significant coefficient of TANGIBLES. Since we take it as a proxy for uncertainty, this result tends to confirm our earlier discussion concerning the relationship between the riskiness and ownership concentration: in a more uncertain environment shareholders may prefer more dispersed ownership. The coefficients of dummies for the type of the largest shareholder appear significant and show that ownership concentration depends on the identity of the owner. For instance, the fact of having a corporation as the largest shareholder increases the share of the largest owner. It should be noted that the impact of size on ownership concentration is not significant

\subsection{Presence of a large shareholder}

Another way of assessing the evolution of the ownership structure is to find out which firms are more likely to find a large owner. We use a probit model to estimate the probability for a firm of finding an owner with at least $20 \%$ of shares in 1999 . The characteristics of the firm in the previous period (1996-1968) are assumed to have influenced the process of ownership concentration.

$$
\begin{aligned}
& \text { OWNER } 20=\alpha+\beta_{1} \text { SIZE }+\beta_{2} \text { TANGIBLES }+\beta_{3} \text { INVESTMENT }+ \\
& \beta_{4} \text { LEVERAGE }+\beta_{5} \text { FIRSTWAVE }+\sum_{j=1}^{4} \gamma_{j} \text { OWNERTYPE }+\sum_{k=2}^{20} \lambda_{k} I N D U S T R Y_{k}+\varepsilon
\end{aligned}
$$

OWNER20 is the probability for a company having an owner with at least $20 \%$ of its shares in 1999. Other variables remain the same as in the previous model. The results of the probit estimation are presented in Table 8.

In this model, size has a negative and significant coefficient, confirming our earlier discussion in Section 4 that larger firms are less likely to have high ownership concentration. The coefficient for TANGIBLES is again positive and significant, indicating that firms in riskier environment (more intangible assets and smaller TANGIBLES) will be less likely to find a large owner, i.e., they will be more likely to have a relatively dispersed ownership structure. Concerning the type of owner, as in the previous regression, firms having corporations as the largest owner are more likely to have a large shareholder with at least $20 \%$ of shares 
Table 8.

Presence of a large owner with at least $20 \%$ of shares. Probit, 1999

\begin{tabular}{lc}
\hline & Coefficient \\
\hline SIZE & $-0.127^{* *}$ \\
TANGIBLES & $(-2.245)$ \\
& 1.233 \\
LEVERAGE & $(2.398)^{* *}$ \\
& 0.796 \\
INVESTMENT & $(1.114)$ \\
& 0.009 \\
FIRST WAVE & $(0.570)$ \\
& -0.357 \\
TYPE OF OWNER: & $(-1.154)$ \\
industrial company & $1.196 * * *$ \\
& $(2.853)$ \\
investment fund & 0.421 \\
& $(0.960)$ \\
another financial institution & 0.513 \\
& $(0.955)$ \\
individual & 0.312 \\
& $(0.691)$ \\
Constant & 1.334 \\
Industry dummies & $(1.610)$ \\
No. of observations & Yes \\
Pseudo R & 571 \\
Log likelihood & 0.1374 \\
\hline
\end{tabular}

Notes: t-ratios in brackets; $*$ significant at $10 \%$; ** significant at 5\%; and *** significant at $1 \%$.

See Appendix 2 for the definition of variables.

\section{Conclusions}

In this paper we compare the evolution of ownership structure in the two countries which adopted two quite different mass privatisation strategies: Poland and the Czech Republic. We find that a significant evolution of ownership structure has taken place in both countries: ownership concentration has significantly increased and new types of owners have largely taken control of the privatised firms. In the Czech Republic, starting from a highly dispersed ownership structure, the large majority of companies have found a dominant shareholder. In nearly half of them, the dominant shareholder owns more than $50 \%$ of equity and has absolute control over the firm. In Poland, starting from a particular ownership structure imposed by the privatisation programme, the majority of companies involved in the scheme has been freed of NIFs' control and has found dominant owners. Overall, it turns out that there has been much flexibility in both schemes with a significant reallocation of ownership claims between 
different groups of shareholders. In particular, corporations and individuals have emerged as important dominant shareholders in both countries. It is interesting to note that although the legal and regulatory environment was initially much poorer in the Czech Republic than in Poland, the trend of concentration and the flexibility of reallocation have been remarkably similar. This observation casts some doubt on the theory which predicts that in countries with better investor protection ownership concentration will be more dispersed (cf. La Porta et al., 1998a).

Having observed the significant evolution of ownership we take ownership structure as endogenous and look at the factors influencing it. We investigate how, after the initial distribution of ownership claims, ownership concentration evolved in response to various pressures and constraints characterizing firms' environment. We find in particular that ownership concentration depends on the degree of uncertainty in the firm's environment. In a more risky environment firms tend to have more dispersed ownership. These results may be interpreted in the light of the recent theories of the firm stressing the trade-off between managerial initiative and shareholder control. 


\section{APPENDIX 1}

\section{Mass Privatisation in the Czech Republic.}

The main method of privatisation in the Czech Republic was 'voucher privatisation' through which some 1700 companies were privatised in two 'waves' in 1991-92 and 1992-94. The shares of these companies were transferred to either individuals or privatisation investment funds (PIFs) in exchange for vouchers. PIFs set up by manufacturing companies, private individuals and institutions as well as state-owned banks and insurance companies, actively participated in the process as financial intermediaries. Adult citizens received vouchers which they could exchange for the shares of companies in the scheme either directly by themselves or indirectly through privatisation investment funds. ${ }^{16}$ In the latter case, they could entrust their vouchers to investment funds and become shareholders of these funds (which were joint stock companies) or unit holders in unit trusts. The funds, in turn, could use vouchers collected from their members to bid for shares of their preferred companies. Understandably, given the prevailing information asymmetry and risk aversion, the majority of citizens opted for the second alternative and entrusted their vouchers to investment funds. In the first wave, $72 \%$ of investment points available were used by funds and $28 \%$ by individuals directly. In the second wave, the percentages were $64 \%$ and $36 \%$ respectively. Moreover, the bulk of investment points controlled by funds were concentrated in the hands of a small number of funds set up by banks and financial institutions (Mládek and Hashi 1993; Brom and Orenstein 1994; Hashi 1998). In the first wave, these funds were all close-end funds but in the second wave many of them took the form of unit trusts. Later on, as part of the reform of the financial system, close-end funds were required to convert themselves to open funds by 2002. Initially, the funds were allowed to hold up to $20 \%$ of the shares of each company in the scheme, though they quickly found ways of bypassing this constraint. The funds' maximum holding in each company was later reduced to $11 \%$.

The shares of mass privatised companies and privatisation investment funds were immediately listed on the stock market without the need for prior approval and the publication of a prospectus. The process of buying and selling of shares, and the reorganisation of funds' portfolios, quickly followed the two waves - a process generally referred to as the 'third wave' of privatisation. Investment funds, despite their large overall stakes, were generally not in a controlling position in their portfolio companies. Many funds had ended up with shares of too many companies and wanted to reduce the size of their portfolios. Many individual shareholders, preferring cash to risky shares, also entered the secondary market, selling their shares, thus further pushing down share prices. ${ }^{17}$ A major feature of the so-called third wave of privatisation was the take-over of investment funds. Given that PIFs (especially those set up in the first wave) were joint stock companies with a large number of shareholders, they were easy targets for aggressive bidders.

\footnotetext{
${ }^{16}$ Vouchers had a nominal value of 1000 investment points. The price of shares of companies in the scheme were also expressed in investment points.

${ }^{17}$ It was estimated that in the early post-privatisation period up to one-third of individuals who had obtained shares in the voucher scheme sold their shares. See The Economist Intelligence Unit, Country Report, 2nd Quarter 1995, p. 15.
} 
The scale of the Polish mass privatisation was less spectacular than the Czech scheme. It included 512 companies and 15 National Investment Funds (NIF), which were set up by the Government. ${ }^{18}$ The management of these funds was initially entrusted to special consortia of Western and Polish partners (commercial banks, investment banks, consulting firms) selected through an international tender offer. The implementation of the programme was delayed by at least four years (1991-95) for political reasons, mainly the absence of a consensus in the government and the parliament about the final list of companies in the scheme, the precise share of different beneficiaries and the specific arrangements concerning corporate governance of the NIFs. The equity of 512 companies was transferred from the state to new owners according to a common scheme: the majority of shares of each company $(60 \%)$ were given to the 15 National Investment Funds, with the remaining $40 \%$ going to employees (15\%) and the Treasury (25\%). For each company, one of the 15 NIFs received $33 \%$ of shares and thus became the "lead fund' for that company. The remaining $27 \%$ were divided between the other 14 funds (each holding just under $2 \%$ of shares). This uniform scheme sharply contrasted with the Czech programme where the outcome of the bidding process was completely unforeseeable and any number of funds, individuals and other beneficiaries could end up as new owners of the companies.

Foreign financial institutions were invited to participate in the programme and, together with Polish institutions, bid for the management of NIFs under lucrative remuneration arrangements. The aim was to bring in the fund management know-how and expertise and ensure that Polish institutions learn from their foreign partners. At the same time, foreign institutions with international reputation were expected to follow the same practice as in their own countries, and not to engage in opportunistic behavior, insider dealing and shareholder expropriation which their inexperienced Polish counterparts may have been tempted to embark on. Many foreign institutions did take part in the programme and most NIFs started to be managed by consortia of foreign and Polish institutions.

The citizens did not become direct shareholders of companies in the scheme but received vouchers (or certificates) which entitled them to one share in each of the 15 Funds, thus becoming indirect shareholders of privatised companies. The stated aim of the programme was for NIFs to restructure their portfolio companies, turn them into market oriented firms and sell them to either strategic owners or on the stock exchange. The Funds themselves were floated on the Warsaw Stock Exchange in June 1997 and the citizens' certificates had to be converted to Funds' shares by the end of 1998. Following a buoyant initial market, and the large-scale sale and purchase of shares, the role of the government began to decline and private owners began to dominate the NIFs. After the first general meetings of shareholders, members of the supervisory boards initially appointed by the government were replaced by members elected by new private shareholders. The direct role of the state in the funds came to an end.

\footnotetext{
18 For details of the Polish mass privatisation, see Hashi (2000).
} 


\section{APPENDIX 2}

List of variables

\begin{tabular}{|c|c|}
\hline Variable & Definition \\
\hline FIRSTWAVE & $\begin{array}{l}\text { A dummy taking the value of } 1 \text { for } \\
\text { companies included in the first wave of } \\
\text { voucher privatisation, and } 0 \text { otherwise }\end{array}$ \\
\hline $\mathrm{C} 1$ & $\begin{array}{l}\text { The share of largest single shareholder of a } \\
\text { company's equity }(\%)\end{array}$ \\
\hline INDUSTRY & $\begin{array}{l}\text { Dummies for } 20 \text { industry groups; based on } \\
\text { Prague Stock Exchange classification } \\
\text { (similar to NACE). The first industry is used } \\
\text { as the base group in regressions. }\end{array}$ \\
\hline INVESTMENT & $\begin{array}{l}\text { The ratio of net investment to total fixed } \\
\text { assets of a company (at constant } 1995 \\
\text { prices), averaged for the 1996-98 period }\end{array}$ \\
\hline $\mathrm{LC} 1$ & $\begin{array}{l}\text { Logistic transformation of } \mathrm{C} 1 \text { (i.e., } \\
\operatorname{Ln}[\mathrm{C} 1 /(100-\mathrm{C} 1)]\end{array}$ \\
\hline LEVERAGE & $\begin{array}{l}\text { The ratio of total debts (long term and short } \\
\text { term) to total assets of a company (both at } \\
\text { constant } 1995 \text { prices), averaged for the } \\
1996-98 \text { period }\end{array}$ \\
\hline OWNER TYPE & $\begin{array}{l}\text { The types of largest shareholder of a } \\
\text { company in } 1999 \text { which are classed into five } \\
\text { groups: } \\
\text { industrial companies } \\
\text { investment funds } \\
\text { other financial institutions (banks or } \\
\text { portfolio companies) } \\
\text { individuals } \\
\text { State (which is used as the base group in } \\
\text { regressions) }\end{array}$ \\
\hline OWNER20 & $\begin{array}{l}\text { The probability of a dominant owner } \\
\text { obtaining at least } 20 \% \text { share of a company's } \\
\text { equity in } 1999\end{array}$ \\
\hline SIZE & $\begin{array}{l}\text { Size of the company, measured by the } \\
\text { natural logarithm of sales (in constant } 1995 \\
\text { prices), averaged for the } 1996-98 \text { period }\end{array}$ \\
\hline TANGIBLES & $\begin{array}{l}\text { The ratio of tangible assets of a company to } \\
\text { its total assets (at constant } 1995 \text { prices), } \\
\text { averaged for the } 1996-98 \text { period }\end{array}$ \\
\hline
\end{tabular}




\section{REFERENCES}

Aghion, P. and O. Blanchard (1998), On Privatization methods in Eastern Europe and their Implications. Economics of Transition, 6(1), pp.87-99.

Aghion, P. and J. Tirole (1997), Formal and real authority in organizations. Journal of Political Economy, 105(1), pp.1-29.

Allen, F. (1993), Stock market and resource allocation, in C. Mayer and X. Vives (eds.) Capital Markets and Financial Intermediation. Cambridge, Cambridge University Press.

Allen, F. and D. Gale (2000), Comparing Financial Systems. Cambridge Mass., The MIT Press.

Becht, M. and A. Röell (1999), Blockholdings in Europe: An International comparison. European Economic Review, 43, pp.1049-1056.

Berle, A. and G. Means (1932), The Modern Corporation and Private Property. New York, Commerce Clearing House.

Bianco, M. and P. Casavola (1999), Italian corporate governance: effects on financial structure and firm performance. European Economic Review, 43, pp.1057-1069.

Brom, K. and M. Orenstein (1994), The privatized sector in the Czech Republic: Government and bank control in a transitional economy. Europe-Asia Studies, 46(6), pp.893-928.

Bolton, P. and E.L. Von Tadden (1998), Blocks, liquidity and corporate control. Journal of Finance, February.

Burkart, M., D. Gromb and F. Panunzi, (1997), Large shareholders, monitoring and the value of the firm. Quarterly Journal of Economics, 112, pp.693-728.

Carlin, W. (1999), The empirical analysis of corporate governance in transition, in F. Boenker, E. Rosenbaum and H.J. Wagener (eds.), Privatization, Corporate Governance and the Emergence of Markets. Basingstoke, MacMillan.

Carlin, W. and C. Mayer (1999), Finance, Investment and growth, CEPR Discussion Paper No. 2233.

Carlin, W., J. Van Reenen and T. Wolfe (1995), Enterprise restructuring in early transition: the case study evidence. Economics of Transition, 3(4), pp.427-458.

Cremer, J. (1995), Arm's length relationships. Quarterly Journal of Economics, 110, pp. 275-300.

De Miquel A., J. Pindado, de la Torre Ch (2001), Ownership structure and firm value: New evidence from the Spanish corporate governance system, SSRN Working Paper No. 292282.

Demsetz, H (1983), The structure of ownership and the theory of the firm. Journal of Law and Economics, 26: 375-390. 
Demsetz, H. and K. Lehn (1985), The structure of ownership: Causes and consequences. Journal of Political Economy, 93(6), pp. 1155-1177.

Demsetz H., B. Villalonga (2001), Ownership structure and corporate performance. Journal of Corporate Finance, 7 (3): 209-233.

Djankov, S. and P. Murrell (2002). Enterprise restructuring in transition: A Quantitative Survey. Journal of Economic Literature, 40(4): 1202-1214.

Estrin, S. and A. Rosevear (1999). Enterprise Performance and Corporate Governance in Ukraine. Journal of Comparative Economics, 27: 442-458.

Fama, E. and M. Jensen (1983), Separation of Ownership and Control. Journal of Law and Economics. 26, pp.301-349.

Frydman, R., C. Gray, M. Hessel, and A. Rapaczynski (1999), When does privatization work? The impact of private ownership on corporate performance in the transition economies. Quarterly Journal of Economics, 114(4), pp. 1153-1191.

Glaeser E., S. Johnson and A. Shleifer (2001), Coase versus the Coasians. Quarterly Journal of Economics, 116 (3), pp. 853-899.

Grosfeld, I. (1997), Financial systems in transition: The role of banks in corporate governance, in K.L. Gupta (ed.) Experiences with Financial Liberalisation. Boston, Dodrecht, London, Kluwer Academic Publishers.

Grosfeld, I. (2002), Exploring the link between privatization and other policies in transition. Paper presented at the conference 'Beyond Transition', CASE, Falenty, 12-13 April.

Grosfeld, I. and J.-F. Nivet (1999), Insiders and wage setting in transition: Evidence from a panel of large Polish firms, 1988-1994. European Economic Review, 43.

Grosfeld I. and T. Tressel (2002), Competition and ownership structure: substitutes or complements? Evidence from the Warsaw Stock Exchange. Economics of Transition, 10 (3), pp. $525-551$.

Hashi, I. (1998), Mass privatisation and corporate governance in the Czech Republic. Economic Analysis, 1(2), pp.163-187.

Hashi, I. (2000), The Polish National Investment Fund programme: Mass privatization with a difference? Comparative Economic Studies, 42(1), pp.87-134.

Heinrich, R.P. (2000), Complementarities in corporate governance: ownership concentration, capital structure, monitoring and pecuniary incentives. Kiel Working Paper No. 968.

Himmbelberg, C.P., R.G. Hubbard and D. Palia (1999), Understanding the determinants of managerial ownership and the link between ownership and performance. Journal of Financial Economics, 53, pp.353-384. 
Holderness, C., R. Kroszner and D. Sheehan (1999), Were the good old days that good?: evolution of managerial stock ownership and corporate governance since the great depression. Journal of Finance, 54, pp.435-469.

Holmström, B. and J. Tirole (1993), Market liquidity and performance monitoring. Journal of Political Economy, 51, pp.678-709.

Jensen, M. and W. Meckling (1976), Theory of the firm: Managerial behavior, agency costs and ownership structure. Journal of Financial Economics, 3, pp.305-360.

La Porta, R, F. Lopez-de-Silanes and A. Shleifer (1998a), Law and Finance. Journal of Political Economy, 106, pp.1113-55.

La Porta, R., F. Lopez-de-Silanes and A. Shleifer (1998b), Corporate Ownership Around the World.. NBER Working Paper No. 6625.

Leech D. and J. Leahy (1991), Ownership structure, control type classifications and the performance of large British companies. The Economic Journal, 101, pp. 1418-1437

McConnell, J. and H. Servaes (1990), Additional evidence on equity ownership and corporate value. Journal of Financial Economics, 2, pp.119-149.

Mejstrik, M. (1997), The Privatisation Process in East-Central Europe: Evolutionary Process of Czech Privatization, Dordecht, Kluwer Academic Publishers.

Mládek, J. and I. Hashi (1993), Voucher privatisation, investment funds and corporate governance in Czechoslovakia. British Review of Economic Issues, 15, No. 37.

Morck, R. (2000), Concentrated Corporate Ownership, The University of Chicago Press, Chicago, London.

Morck, R., A. Shleifer and R. Vishny (1988), Management ownership and market valuation. Journal of Financial Economics, 20 (1-2): 293-315.

Nickell, S.J., D. Nicolitsas and N. Dryden (1997), What makes firm perform well?, European Economic Review, 41: 783- 796.

Shleifer, A. and R. Vishny (1986), Large shareholders and corporate control. Journal of Political Economy, 94: 461-488.

Short H. (1994), Ownership, control, financial structure and the performance of firms. Journal of Economic Surveys, 8 (3), pp. 203-249. 


\section{DAVIDSON INSTITUTE WORKING PAPER SERIES - Most Recent Papers}

The entire Working Paper Series may be downloaded free of charge at: www.wdi.bus.umich.edu

CURRENT AS OF $7 / 21 / 03$

\begin{tabular}{|c|c|c|}
\hline Publication & Authors & Date \\
\hline $\begin{array}{l}\text { No. 596: Mass Privatisation, Corporate Governance and Endogenous } \\
\text { Ownership Structure }\end{array}$ & Irena Grosfeld & July 2003 \\
\hline No. 595: WTO Accession: What's in it for Russia? & Abdur Chowdhury & July 2003 \\
\hline No. 594: The Political-Economy of Argentina's Debacle & Marcos A. Buscaglia & July 2003 \\
\hline $\begin{array}{l}\text { No. 593: While Labour Hoarding May Be Over, Insiders' Control Is } \\
\text { Not. Determinants of Employment Growth in Polish Large Firms, } \\
\text { 1996-2001 }\end{array}$ & $\begin{array}{l}\text { Kate Bishop and Tomasz } \\
\text { Mickiewicz }\end{array}$ & July 2003 \\
\hline $\begin{array}{l}\text { No. 592: Globalization and Trust: Theory and Evidence from } \\
\text { Cooperatives }\end{array}$ & $\begin{array}{l}\text { Ramon Casadesus-Masanell and } \\
\text { Tarun Khanna }\end{array}$ & June 2003 \\
\hline $\begin{array}{l}\text { No. 591: Restructuring or Disintegration of the German Corporate } \\
\text { Network: Globalization as a Fifth Column }\end{array}$ & Bruce Kogut and Gordon Walker & June 2003 \\
\hline $\begin{array}{l}\text { No. 590: Institutional Change and Firm Creation in East-Central } \\
\text { Europe: An Embedded Politics Approach }\end{array}$ & Gerald A. McDermott & June 2003 \\
\hline $\begin{array}{l}\text { No. 589: Legitimacy, Interest Group Pressure and Institutional Change: } \\
\text { The Case of Foreign Investment and Host Country Governments }\end{array}$ & $\begin{array}{l}\text { Witold J. Henisz and Bennet A. } \\
\text { Zelner }\end{array}$ & June 2003 \\
\hline $\begin{array}{l}\text { No. 588: Institutions and the Vicious Circle of Distrust in the Russian } \\
\text { Household Deposit Market, 1992-1999 }\end{array}$ & Andrew Spicer and William Pyle & June 2003 \\
\hline $\begin{array}{l}\text { No. 587: Foreign Direct Investment and the Business Environment in } \\
\text { Developing Countries: the Impact of Bilateral Investment Treaties }\end{array}$ & $\begin{array}{l}\text { Jennifer Tobin and Susan Rose- } \\
\text { Ackerman }\end{array}$ & June 2003 \\
\hline No. 586: Trust in China: A Cross-Regional Analysis & Rongzhu Ke and Weiying Zhang & June 2003 \\
\hline No. 585: Family Control and the Rent-Seeking Society & $\begin{array}{l}\text { Randall Morck and Bernard } \\
\text { Yeung }\end{array}$ & June 2003 \\
\hline $\begin{array}{l}\text { No. 584: Wage Determination: Privatised, New Private and State } \\
\text { Owned Companies, Empirical Evidence from Panel Data }\end{array}$ & $\begin{array}{l}\text { Tomasz Mickiewicz and Kate } \\
\text { Bishop }\end{array}$ & June 2003 \\
\hline No. 583: An Investigation of Firm-Level R\&D Capabilities in East Asia & $\begin{array}{l}\text { Gary H. Jefferson and Zhong } \\
\text { Kaifeng }\end{array}$ & June 2003 \\
\hline $\begin{array}{l}\text { No. 582: R\&D and Technology Transfer: Firm Level Evidence From } \\
\text { Chinese Industry }\end{array}$ & $\begin{array}{l}\text { Albert G.Z. Hu, Gary H. } \\
\text { Jefferson, Guan Xiaojing and } \\
\text { Qian Jinchang }\end{array}$ & June 2003 \\
\hline $\begin{array}{l}\text { No. 581: Credit Market Disequilibrium in Poland: Can We Find } \\
\text { What We Expect? Non-Stationarity and the "Min" } \\
\text { Condition }\end{array}$ & $\begin{array}{l}\text { Christophe Hurlin †and Rafal } \\
\text { Kierzenkowski }\end{array}$ & June 2003 \\
\hline $\begin{array}{l}\text { No. 580: Does it Take a Lula to go to Davos? } \\
\text { A Brief Overview of Brazilian Reforms, 1980-2000 }\end{array}$ & $\begin{array}{l}\text { Nauro F. Campos, Armando } \\
\text { Castellar Pinheiro, Fabio } \\
\text { Giambiagi and Maurício M. } \\
\text { Moreira }\end{array}$ & June 2003 \\
\hline $\begin{array}{l}\text { No. 579: Ceaseless Toil? Health and Labor Supply of the Elderly in } \\
\text { Rural China }\end{array}$ & $\begin{array}{l}\text { Dwayne Benjamin, Loren Brandt } \\
\text { and Jia-Zhueng Fan }\end{array}$ & June 2003 \\
\hline $\begin{array}{l}\text { No. 578: Shadow Economy, Rent-Seeking Activities and the Perils of } \\
\text { Reinforcement of the Rule of Law }\end{array}$ & Ekaterina Vostroknutova & June 2003 \\
\hline $\begin{array}{l}\text { No. 577: No Pain, No Gain: Market Reform, Unemployment, and } \\
\text { Politics in Bulgaria }\end{array}$ & Neven Valev & June 2003 \\
\hline $\begin{array}{l}\text { No. 576: Power Analysis of the Nice Treaty On the Future of European } \\
\text { Integration }\end{array}$ & Yener Kandogan & June 2003 \\
\hline $\begin{array}{l}\text { No. 575: Democracy’s Spread: Elections and Sovereign Debt in } \\
\text { Developing Countries }\end{array}$ & $\begin{array}{l}\text { Steven A. Block, Burkhard N. } \\
\text { Schrage, and Paul M. Vaaler }\end{array}$ & June 2003 \\
\hline $\begin{array}{l}\text { No. 574: Reintroducing Intergenerational Equilibrium: Key Concepts } \\
\text { Behind the New Polish Pension System }\end{array}$ & Marek Góra & June 2003 \\
\hline $\begin{array}{l}\text { No. 573: Why Does FDI Go Where It Goes? New Evidence From the } \\
\text { Transition Economies }\end{array}$ & $\begin{array}{l}\text { Yuko Kinoshita and Nauro F. } \\
\text { Campos }\end{array}$ & June 2003 \\
\hline $\begin{array}{l}\text { No. 572: Private Savings in Transition Economies: Are There Terms of } \\
\text { Trade Shocks? }\end{array}$ & Abdur R. Chowdhury & May 2003 \\
\hline
\end{tabular}

